\title{
Two new species of Leporinus Agassiz, 1829 from Araguaia-Tocantins system, Amazon basin, Brazil (Ostariophysi, Anostomidae)
}

\author{
Garavello, JC. ${ }^{\mathrm{a} *}$ and Santos, GM. ${ }^{\mathrm{b} *}$ \\ aDepartamento de Ecologia e Biologia Evolutiva, Universidade Federal de São Carlos - UFSCar, \\ Rodovia Washington Luis, Km 235, CP 676, CEP 13565-905, São Carlos, SP, Brazil \\ 'Instituto Nacional de Pesquisas da Amazônia - INPA, \\ Av. André Araújo, 2936, Petrópolis, CEP 69083-000, Manaus, AM, Brazil \\ *e-mail: garavelo@power.ufscar.br, gsantos@inpa.gov.br \\ Received October 13, 2002 - Accepted July 16, 2007 - Distributed February 28, 2009 \\ (With 6 figures)
}

\begin{abstract}
Two new species of genus Leporinus from the Araguaia-Tocantins system, Amazon, Brazil, are described. Leporinus unitaeniatus $\mathrm{n}$. $\mathrm{sp}$. is distinguished from the remaining species of this genus by the presence of a conspicuous longitudinal dark brown bar along the lateral line on the flanks, and Leporinus geminis $\mathrm{n}$. sp. is distinguished by an inconspicuous dark bar combined with three large and vertically elongated brown blotches on the trunk; the first on the dorsal fin region, the second anterior to the adipose fin and the third on the caudal peduncle. Both are medium-sized species of the genus (up to $150 \mathrm{~mm} \mathrm{SL}$ ) and share the following combination of meristic characters: 4 teeth on each premaxillary and dentary; 40-43 scales in the lateral line, 6/I/5 scales on the transversal line, and 16 series of scales around the caudal peduncle. L. unitaeniatus n. sp. has a sub-terminal mouth and tooth series formed by incisive-like elongated teeth frontally turned and with only a straight cutting edge decreasing in size like the steps of stairs from the teeth pair of symphysis. Leporinus geminis n. sp. has a sub-inferior mouth and the tooth series shaped by large incisive-like teeth forming an arched cutting edge, decreasing in size from the symphysal pair of teeth.
\end{abstract}

Keywords: Neotropics, freshwater fishes, systematic, Araguaia-Tocantins, Brazil.

\section{Duas novas espécies de Leporinus Agassiz, 1829 do sistema hidrográfico Araguaia-Tocantins, Amazônia, Brasil (Ostariophysi, Anostomidae)}

\section{Resumo}

Duas novas espécies do gênero Leporinus originárias dos rios Araguaia e Tocantins são descritas e distinguidas das demais espécies desse gênero na bacia Amazônica. Leporinus unitaeniatus sp. n., por possuir uma fina listra longitudinal castanho-escura ao longo da linha lateral e 12 a 15 barras transversais castanho-escuras sobre o dorso que não alcançam a linha lateral. Leporinus geminis sp. n., por apresentar uma larga listra longitudinal castanho-escura ao longo da linha lateral entre a vertical com origem da nadadeira pélvica e a nadadeira caudal e duas ou três largas manchas castanho-escuras verticalmente alongadas sobre o tronco: abaixo da nadadeira dorsal, na região anterior à nadadeira adiposa e sobre o pedúnculo caudal. Ambas são espécies de médio porte do gênero (em torno de $150 \mathrm{~mm}$ $\mathrm{CP}$ ) e podem ser diagnosticadas pela seguinte combinação de caracteres merísticos: 4/4 dentes, 40-43 escamas na linha lateral, 6/I/5 escamas na linha transversal e 16 escamas circumpedunculares. Leporinus unitaeniatus sp. n. apresenta a abertura bucal em posição subterminal e a arcada dentária composta por dentes incisiviformes alongados de borda cortante simples, voltados para a frente e decrescendo progressivamente de tamanho a partir do par da sínfise. Leporinus geminis sp. n. se caracteriza pela posição subinferior da boca e pela arcada dentária formada por dentes incisiviformes largos, de borda cortante escavada internamente, também decrescendo em tamanho a partir da sínfise dentária.

Palavras-chave: peixes de água doce, Neotropica, sistemática, Araguaia-Tocantins, Brasil.

\section{Introduction}

The last comprehensive revision of the genus Leporinus Agassiz was an unpublished thesis manuscript (Garavello, 1979) which included ten undescribed species. Among these species, one, described

below, Leporinus unitaeniatus, was diagnosed based on six specimens from the Rio Araguaia and one specimen from the Rio Tapajós. Subsequent collecting efforts yielded additional ichthyological collections of 
genus Leporinus from these basins. The new material allowed the proper description of this new species and the conclusion that the specimens from Rio Tapajós basin belonged to another new species described elsewhere by Britski and Garavello (2005). Also recent collectors in Rio Tocantins gathered a large collection thereby making possible the adjoining of the description of Leporinus geminis n. sp., a sympatric species, to that of L. unitaeniatus.

The species of the genus Leporinus from the Rio Tocantins basin has received very little attention as discussed by Britski (1997). Valenciennes (1850) based on ichthyological material collected by Castelnau, described Leporinus pachyurus Vallenciennes, 1849 and made references to Leporinus maculatus Müller and Troschel, 1844 and Leporinus obtusidens Valenciennes, 1849 from the Rio Vermelho, a tributary of the Rio Araguaia in Goias State. On the other hand, Castelnau (1855) reappraised the specimens of this collection and described Leporinus bimaculatus n. sp. from the Rio Vermelho at São João das Duas Barras, based on the specimens identified by Valenciennes as Leporinus obtusidens. He also cited the localities of Crixás for the specimens of Leporinus maculatus and Rio Araguaia for the specimens of Leporinus pachyurus (referred by Castelnau as brachyurus).

Specimens fitting the description of L. bimaculatus were never collected in that basin since the expeditions of Castelnau in 1844. Also Leporinus pachyurus was poorly described, and the type-material is missing from the National Museum of Natural History in Paris.

Seventy-four years later, Borodin (1929) described Leporinus fasciatus tigrinus, a species considered valid as Leporinus tigrinus Borodin, 1929 by Garavello and Britski (2003). He also cited Leporinus affinis Günther, 1864 and a new species from this basin. Other species from the Rio Tocantins basin were recognized by Santos and Jégu (1989), who cited L. friderici (Bloch, 1794), L. trifasciatus Steindachner, 1876, L. desmotes Fowler, 1914, L. granti Eigenmann , 1912, L. pachycheylus Britski , 1976 and four species diagnosed under the name Leporinus sp. It is important to recognize that the species cited by those authors as Leporinus sp. 1, and Leporinus sp. 2 are in fact L. unitaeniatus n. sp. and L. geminis $\mathrm{n}$. sp. herein described.

After this, only Britski (1997) described additional species for that basin, namely Leporinus taeniofasciatus from Rio Maranhão, and Leporinus bistriatus from Rio Itacaiunas. Furthermore, recent collections were made by the authors in the region of Tocantinópolis, Itupiranga and Itaguatins at mid Rio Tocantins and additional ichthyological material was gathered from collections of the Instituto Nacional de Pesquisas da Amazônia permitting the description of those species from the AraguaiaTocantins system. This article benefitted from the rank of Leporinus Agassiz species formerly presented by Garavello and Britski (2003).

\section{Material and Methods}

Measurements and counts were obtained according to the methods previously outlined by Garavello and Britski (1988) in addition to mid-dorsal scale count taken from the supraoccipital bone and origin of dorsal fin insertion and between the adipose-fin and the origin of caudal fin rays. Also scale counts were taken from the ventral median line between the isthmus and the pelvic fin, between this fin and anal opening, between the anus to anal fin origin and from this fin to the caudal fin insertion. Examined material are housed at the Museu de Zoologia of the University of São Paulo (MZUSP), the National Institute of Amazon Research (INPA) and at the Laboratório de Ictiologia Sistemática of the Departamento de Ecologia e Biologia Evolutiva of the Federal University of São Carlos (LISDEBE).

Leporinus unitaeniatus, sp. n. (Figure 1)

Leporinus “ unitaeniatus": Johannes, 1999: BSWW Report, Nr. 3: 15 (reference).

Leporinus sp. 1: Santos and Jégu, 1989: 173, pl. II, figure 7, table 1 (diagnosis and reference).

Holotype: Mato Grosso State: MZUSP 14427, $105.5 \mathrm{~mm}$ SL, Santa Terezinha, Rio Araguaia, H. A. Britski, October 1964.

Paratypes: Mato Grosso State: MZUSP 14429, 5, 70.0-125.0 mm SL, same locality and collector of holotype. Tocantins State: MZUSP 14430, 1, $125.0 \mathrm{~mm} \mathrm{SL}$, Rio Tocantins, upriver from Imperatriz, J. C. Garavello, M. L. Musarra and F. M. S. Braga, June 1988; MZUSP 14431, 2, 92.5 to $112.5 \mathrm{~mm}$ SL, Tocantinópolis, Rio Tocantins, at Rio Lageado mouth, J. C. Garavello, M. L. Musarra and F. M. S. Braga, 14-18 June 1988; LISDEBE $1513,3,87.7$ to $106.0 \mathrm{~mm}$ SL, Rio Tocantins between Itaguatins and Santo Antonio falls, Itaguatins, J. C. Garavello, M. L. Musarra and F. M. S. Braga, 14-18 June 1988.

Para State: MZUSP 14424, 1, $120.0 \mathrm{~mm}$ SL, Itupiranga, Rio Tocantins, P. C. Vênere, June 1988; INPA 1572, 2, 80.0 and $90.0 \mathrm{~mm}$ SL, Igarapé Valentim, left bank tributary of Rio Tocantins, on the Tucuruí to Marabá road, G. M. Santos, 24 ${ }^{\text {th }}$ November 1981; INPA 1574, 12 , 35.0-95.0 mm SL, Itupiranga, Igarapé Vermelho, left bank tributary of Rio Tocantins, G. M. Santos, 23 November 1981; INPA 1575, 4, 119.0-122.0 mm SL, Tucuruí, Rio Tocantins, Breu Branco, upriver from Tucuruí hydroelectric power dam, G. M. Santos, 13 November 1981; INPA

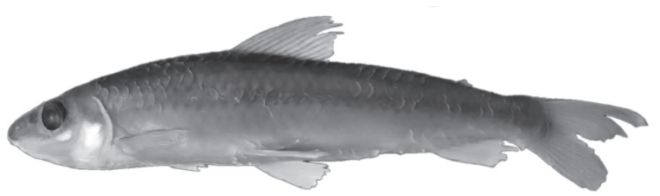

Figure 1. Leporinus unitaeniatus n. sp.: MZUSP 14429 , paratype, $120 \mathrm{~mm} \mathrm{SL}$, lateral view. 
1576, 8, 95.0-155.0 mm SL, Tucuruí, Rio Tocantins, upriver from Tucuruí hydroelectric power dam, G. M. Santos, 12 November 1984; INPA 1577, 13, 105.0130.0 mm SL, Tucuruí, Capuerana, Rio Tocantins, upriver from Tucuruí hydroelectric power dam, G.M. Santos, 13 November 1981; INPA 1919, 1, 95.0 mm SL, Tucuruí, Rio Tocantins, upriver from Tucuruí, hydroelectric power dam, G. M. Santos, 11 November 1984; INPA 1920, 1, 112.0 mm SL, Tucuruí, Rio Tocantins, Acarí Pucu, downriver from the Tucuruí hydroelectric power dam, G. M. Santos, 27 March 1982; INPA 1921, 1, 125.0 mm SL, Tucuruí, Rio Tocantins, Capuerana, upriver from Tucuruí, hydroelectric power dam, G.M. Santos, 10 November 1981; INPA 1922, 1, 113.0 mm SL, Rio Tocantins, Breu Branco, upriver from Tucurui hydroelectric power dam, G. M. Santos, November, 1980; INPA 1923, 2, 78.0 and $83.0 \mathrm{~mm}$ SL, Cametá, Rio Tocantins, G. M. Santos, 22 July 1982; INPA 1924, 1, 72.0 mm SL, Tucuruí, Rio Tocantins, Poço do Paulo, downriver from the Tucuruí hydroelectric power dam, G. M. Santos, 26 June 1980; INPA 1925, 1, 70.0 mm SL, Itupiranga, Igarapé Vermelho, tributary of Rio Tocantins, G. M. Santos, 23 November 1981.

Diagnosis: Leporinus unitaeniatus n. sp. is distinguished from the remaining species of the genus by its color pattern: one longitudinal narrow brown stripe running along lateral line, light brown on the first 10-11 scales after opercular opening and dark brown along the posterior remaining scales of lateral line; 11-13 short transverse dark brown bars on dorsum meeting small dark brown blotches. This species also differ from its congeners by combination of following characters: snout slender (its length 38.4 to $50.6 \%$ in head length); eyes small (orbital diameter 24.6 to $30.9 \%$ in head length); body very narrow and elongated (its depth 17.7 to $24.6 \%$ of SL), sub inferior mouth (inferior margin of superior lip horizontally aligned with the inferior margin of orbit). Teeth elongated incisive-like and with a fine and straight cutting edge decreasing in size like the steps of stairs from teeth pair of jaw symphysis. 4/4 teeth on each premaxillary and dentary; 42 to 44 scales in the lateral line, 6 scales series above and 5 under the lateral line on the transverse line and 16 circumpeduncular series of scales.

Description: medium-sized species; largest specimen $125.0 \mathrm{~mm}$ SL. Body elongated, its depth corresponding to $17.7 \%$ to $24.6 \%$ of SL; head length higher than body depth, $21.7 \%$ to $25.8 \%$ of SL. Other morphometric traits are expressed in Table 1. Mouth sub inferior; upper lip horizontally aligned with inferior margin of orbit; snout truncated and not prominent in ventral view. Dorsal profile from anterior margin of snout to origin of dorsal fin insertion slightly convex and very little arched; almost straight at dorsal-fin base and straight from dorsal-fin terminus to adipose fin; concave at caudal peduncle between adipose and caudal fin; ventral profile convex in slight uniform curvature from inferior mandible to vertical through pectoral-fin basis and almost straight from this point to origin of anal-fin insertion; straight at anal-fin base and concave at caudal peduncle between distal anal and caudal-fin insertion.

Dorsal-fin rays reaching from dorsal-fin terminus reaching five or six dorsal scales when adpressed. Pectoral-fin tip reaching five to six lateral body scales when adpressed; pelvic fin reaching four or five abdominal scales before anal opening. Anal-fin elongated, its last rays almost reaching caudal fin base, distant only one or two scales from lower caudal fin insertion; posterior margin of anal fin rounded when extended. Caudal fin forked; upper lobe longer than lower.

Lateral line complete, with 42 to 44 perforated scales; transversal line with 6 series of scales above and 5 under lateral line; 16 circumpeduncular series of scales; median dorsal line of trunk with 13-14 scales between supraoccipital and origin of dorsal-fin insertion, 12-13 between dorsal and adipose fins and 8-9 between adipose-fin and upper caudal-fin insertion; median ventral line with 18 to 21 scales between istmus and pelvic fins; 9 to 11 between pelvic fins and anal opening; 3 ( 2 or 4) between anus and anal fin and 6 to 8 between anal fin and lower caudal-fin insertion. Four teeth inserted on each premaxillary and four on each dentary; each tooth elongated incisive-like in both jaws and with a straight cutting edge; teeth decreasing in size like stair steps from largest teeth pair of symphysis (Figure 3). Dorsal fin, i (ii) +9 rays; pectoral fin, $i+15$ rays; pelvic fin, $i+$ 8; anal fin: $\mathrm{ii}+7$ and caudal fin, $\mathrm{i}+17+\mathrm{i}$.

Color pattern of preserved specimens: Body with a longitudinal median dark brown stripe as wide as lateral line scale series; it starts inconspicuously from snout tip through eyes, interrupted by the light opercular membrane and running inconspicuously on lateral line scales to median region of trunk; at this point meeting an inconspicuous elongated light brown blotch. From this point to caudal peduncle it is a conspicuous dark brown elongated stripe, along lateral line and meeting a small round dark brown blotch on caudal peduncle; some individuals with the anterior portion of this stripe absent from snout to vertical through dorsal-fin origin. Along whole dorsum, mainly on juvenile specimens, 11 to 13 short transversal dark brown bars meeting small dark brown blotches above median longitudinal stripe. Head light brown with two dark brown bars crossing dorsally on interorbital space and on supraoccipital bone; snout and anterior region of eyes light brown. Membrane fins hyaline; very few light brown chromatophores concentrated on margin of fins mainly on pectoral and dorsal fins.

Distribution: L. unitaeniatus is known from the Rios Araguaia and Tocantins.

Etymology: The specific name unitaeniatus is an adjective in allusion to the single, slender and horizontal dark brown stripe on the lateral line exhibited by this species.

\section{Leporinus geminis $\mathrm{n}$. sp. (Figure 2)}

Leporinus sp. 2: Santos, 1989: 173, plate II, figure 6 , table 1 (diagnosis and reference). 
Table 1. Morphometrics of L. geminis, L. unitaeniatus and L. taeniatus expressed as percentages of SL (2-6) and HL (7-9).

\begin{tabular}{|c|c|c|c|c|c|}
\hline \multirow[t]{3}{*}{ Characters } & \multicolumn{5}{|c|}{ L. geminis $(\mathrm{n}=12)$} \\
\hline & \multirow{2}{*}{$\begin{array}{c}\text { Holotype } \\
\text { (mm) }\end{array}$} & \multicolumn{2}{|c|}{ Range } & \multirow[t]{2}{*}{ Mean } & \multirow[t]{2}{*}{ SD } \\
\hline & & Low & High & & \\
\hline 1) Standard length (mm) & 140.0 & 120.0 & 180.0 & 144.25 & - \\
\hline 2) Head length & 34.0 & 23.24 & 26.96 & 25.12 & 0.011 \\
\hline 3) Trunk length & 106.0 & 73.04 & 76.76 & 74.88 & 0.011 \\
\hline 4) Body depth & 34.0 & 21.67 & 26.07 & 23.79 & 0.012 \\
\hline 5) Predorsal distance & 61.8 & 42.76 & 48.62 & 45.24 & 0.019 \\
\hline 6) Caudal peduncle depth & 13.8 & 9.16 & 10.36 & 9.73 & 0.004 \\
\hline 7) Snout length & 15.2 & 39.02 & 47.62 & 44.47 & 0.027 \\
\hline 8) Interorbital distance & 15.0 & 35.96 & 45.40 & 40.96 & 0.025 \\
\hline 9) Orbital diameter & 9.0 & 21.46 & 27.89 & 25.49 & 0.020 \\
\hline \multirow[t]{3}{*}{ Characters } & \multicolumn{5}{|c|}{ L. unitaeniatus $(\mathrm{n}=12)$} \\
\hline & \multirow{2}{*}{$\begin{array}{c}\text { Holotype } \\
(\mathrm{mm})\end{array}$} & \multicolumn{2}{|c|}{ Range } & \multirow[t]{2}{*}{ Mean } & \multirow[t]{2}{*}{ SD } \\
\hline & & Low & High & & \\
\hline 1) Standard length (mm) & 105.5 & 70.0 & 125.0 & 96.73 & - \\
\hline 2) Head length & 25.6 & 21.79 & 25.89 & 24.10 & 0.004 \\
\hline 3) Trunk length & 79.9 & 74.11 & 78.21 & 75.97 & 0.011 \\
\hline 4) Body depth & 25.2 & 17.76 & 24.62 & 22.25 & 0.019 \\
\hline 5) Predorsal distance & 48.3 & 43.20 & 50.44 & 46.11 & 0.019 \\
\hline 6) Caudal peduncle depth & 8.5 & 7.44 & 8.86 & 8.16 & 0.004 \\
\hline 7) Snout length & 10.3 & 38.43 & 50.64 & 42.02 & 0.030 \\
\hline 8) Interorbital distance & 9.4 & 33.19 & 48.07 & 37.19 & 0.041 \\
\hline 9) Orbital diameter & 6.8 & 24.65 & 30.92 & 27.83 & 0.019 \\
\hline \multirow[t]{3}{*}{ Characters } & \multicolumn{5}{|c|}{ L. taeniatus $(\mathrm{n}=12)$} \\
\hline & \multirow{2}{*}{$\begin{array}{c}\text { Holotype } \\
(\mathrm{mm})\end{array}$} & \multicolumn{2}{|c|}{ Range } & \multirow[t]{2}{*}{ Mean } & \multirow[t]{2}{*}{ SD } \\
\hline & & Low & High & & \\
\hline 1) Standard length (mm) & - & 80.0 & 170.0 & 132.8 & - \\
\hline 2) Head length & - & 22.4 & 26.88 & 24.57 & 0.014 \\
\hline 3) Trunk length & - & 73.13 & 77.06 & 75.43 & 0.014 \\
\hline 4) Body depth & - & 25.17 & 29.13 & 26.84 & 0.016 \\
\hline 5) Predorsal distance & - & 44.12 & 47.88 & 45.98 & 0.013 \\
\hline 6) Caudal peduncle depth & - & 9.52 & 11.25 & 10.30 & 0.006 \\
\hline 7) Snout length & - & 43.55 & 44.67 & 44.06 & 0.005 \\
\hline 8) Interorbital distance & - & 40.32 & 43.23 & 41.57 & 0.011 \\
\hline 9) Orbital diameter & - & 16.67 & 25.12 & 20.58 & 0.031 \\
\hline
\end{tabular}

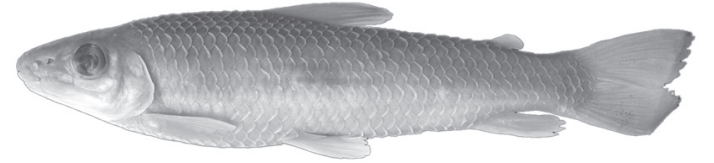

Figure 2. Leporinus geminis n. sp.: MZUSP 14422, holotype, $140 \mathrm{~mm} \mathrm{SL}$, lateral view.
Holotype: MZUSP 14422, 140.0 mm SL, Brazil, Pará State, Marabá, Rio Tocantins, R. S. Rosa, 18 October11 November 1974.

Paratypes: Pará State: MZUSP 14425, 2, 87.0 and $123.0 \mathrm{~mm}$ SL, same locality and collector of holotype; MZUSP 14426,1, $130.0 \mathrm{~mm}$ SL, Itupiranga, Rio Tocantins, P. C. Vênere, June 1988; INPA 1590, 


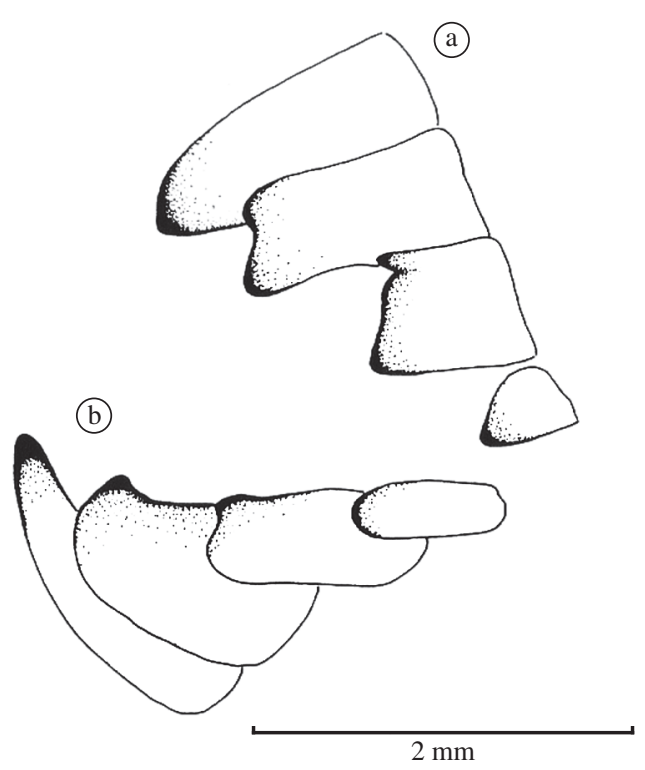

Figure 3. Lateral view of premaxillary a) and dentary teeth b) of L. unitaeniatus (after Santos and Jégu, 1989).

2, 138.1 and $139.1 \mathrm{~mm}$ SL, Tucuruí, Capuerana, Rio Tocantins, upriver from Tucuruí hydroelectric power dam, G. M. Santos, 10 November 1981; INPA 1591, 7, 140.0-156.0 mm SL, Itupiranga, Rio Tocantins, upriver from Tucuruí hydroelectric power dam, G. M. Santos, 16 November 1980; INPA 1592, 2, 120.0 and $125.0 \mathrm{~mm}$ SL, Itupiranga, Igarapé Valentim, tributary of Rio Tocantins, G. M. Santos, 21 November 1981; INPA 1927, 1, 162.0 mm SL, Tucuruí, Rio Tocantins, at reservoir of Tucuruí hydroelectric power dam, M. Jegú, 5 February 1985; INPA 1928, 2, 150.0 and 170.0 mm SL, Tucuruí, Rio Tocantins, pool downriver of Tucuruí hydroelectric power dam, G. M. Santos, October 1984; INPA 1929, 1, $106.0 \mathrm{~mm}$ SL, Capuerana, upriver from Tucuruí hydroelectric power dam, G. M. Santos, 10 November 1981; INPA 1930, 1, 123.0 mm SL, Itupiranga, Rio Tocantins, G. M. Santos, 15 July 1981; INPA 1931, 1, 131.0 mm SL, Tucuruí, pool downriver from Tucuruí hydroelectric power dam, G. M. Santos, 22 October 1984; INPA 1932, 1, 160.0 mm SL, Breu Branco, Rio Tocantins, upriver from Tucuruí hydroelectric power dam, G. M. Santos, 13 November 1981; INPA 1933, 4, 115.0-180.0 mm SL, Capuerana, Rio Tocantins, upriver from Tucurui hydroelectric power dam, G. M. Santos, 10 November 1981; INPA 1934, 4, 125-135 mm SL, Itupiranga, Rio Tocantins, G. M. Santos, November 1980; INPA 1935, 1, $135.0 \mathrm{~mm}$ SL, Breu Branco, Rio Tocantins, upriver from Tucuruí hydroelectric power dam, G. M. Santos, November 1980. Tocantins State: LISDEBE 1512, 1, 180.0 mm SL, Rio Lageado, tributary of Rio Tocantins on the road Belém-Brasília, J. C. Garavello, M. L. Musarra and F. M. S. Braga, 17-18 June 1988.

Diagnosis: Leporinus geminis $\mathrm{n}$. $\mathrm{sp}$. is distinguished from the remaining species of the genus Leporinus by its color pattern of: one longitudinal and discontinuous narrow dark brown stripe running inconspicuously from a vertical through middle of dorsal fin to base of caudal peduncle along lateral line; two or three large dark brown vertically elongated blotches along middle trunk: first at the vertical through dorsal-fin, second anterior to adipose fin and third on the caudal peduncle; mainly in young specimens, 12-13 short transversal dark brown bars meeting small dark brown blotches laterally. The species also differs from its congeners by the combination of the following characters: snout blunt (its length 39 to $47.6 \%$ in head length); orbits large (orbital diameter 21.4 to $27.8 \%$ of head length) body high (its depth 21.6 to $26.0 \%$ of SL), sub-inferior mouth (inferior margin of superior lip horizontally aligned with the inferior margin of infraorbital bones), 4 teeth on each premaxillary and dentary; teeth gross incisive-like, forming an arched cutting edge, decreasing in size from the symphysal largest pair; 40 to 42 scales in the lateral line, 5,5 or 6 scales series above and 5 under lateral line and 16 circumpeduncular series of scales.

Description: Medium-sized species, largest specimen $180.0 \mathrm{~mm}$ SL. Body high, its depth corresponding to 21.6 to $26 \%$ of SL; head length 23.2 to $26.9 \%$ of SL. Other morphometric traits are expressed in Table 1. Mouth sub-inferior; upper lip horizontally aligned with inferior margin of infraorbital bones; snout blunt, prominent in relation to mouth opening in ventral view. Dorsal profile almost straight from dorsal margin of snout to the supraoccipital bone; convex from this point to end of dorsal-fin insertion; convex from dorsal-fin terminus to caudal peduncle; ventral profile a straight from lower mandible to pectoral-fin insertion, slight curved from that point to pelvic-fin origin; straight from pelvic-fin to anal-fin origin; almost straight at anal-fin base and anus; concave at caudal peduncle between anal-fin base and caudal-fin insertion.

Dorsal-fin rays reaching six or seven dorsal scales posterior to its basis when adpressed. Pectoral-fin tip reaching eight to nine lateral body scales posterior to its basis when adpressed; pelvic-fin reaching five or six abdominal scales before anal opening. Anal fin elongated, last rays almost reaching caudal-fin base, distant only one or two scales from lower caudal-fin rays; posterior margin of anal fin rounded. Caudal fin forked; upper and lower lobes almost equal in size.

Lateral line complete, with 40 to 42 perforated scales; transversal line with 5.5 or 6 series of scales above and 5 under lateral line; 16 circumpeduncular series of scales. Median dorsal line of trunk with 15-16 scales between supraoccipital and dorsal-fin origin, 11-13 between dorsal fin and adipose fin and 8-9 between adipose fin and upper caudal-fin insertion. Median ventral line with 18 to 20 scales between isthmus and pelvic fins; 8 to 11 between pelvic fins and anal opening; 3-4 between anus and anal fin and 5 to 8 between anal fin and lower caudal-fin insertion. Four teeth inserted like stair steps on each premaxillary and on each dentary; teeth like gross- 
incisive, forming an arched cutting edge decreasing in size from symphysal largest teeth pair (Figure 4). Dorsal fin, ii (iii) +9 rays; pectoral fin, $\mathrm{i}+15$ (16) rays; pelvic fin, $i+8$ (9); anal fin: $i i+7$ and caudal fin, $i+17+i$.

Color pattern of preserved specimens: A lateral and discontinuous narrow dark brown stripe running inconspicuously on lateral line from a vertical through middle dorsal fin to base of caudal peduncle; two or three large dark brown vertically elongated blotches along middle trunk: first vertically aligned with dorsal fin, second anterior to adipose fin and third on caudal peduncle. Dorsum of juvenile specimens with 12-13 short transversal dark brown bars meeting small dark brown blotches laterally to median trunk, not meeting lateral line stripe. Head yellowish; two or three inconspicuous dark brown bars crossing dorsally on interorbital space, on anterior supraoccipital bone and when present on caudal peduncle; membrane fins hyaline; light brown chromatophores concentrated on margins of pectoral and dorsal fins.

Distribution: L. geminis is known from Rio Tocantins (Figure 6).

Etymology: The specific name geminis is given in allusion to the similarity showed by the young of this species with its co-generic Leporinus unitaeniatus n. sp.

\section{Discussion}

The genus Leporinus Agassiz is known by its numerous species summarized by Garavello and Britski (2003). Borodin (1929) proposed the subgenus Hypomasticus to receive species anatomically distinguished by their sub inferior or inferior mouth, division subsequently accepted only by Géry (1960). Because the lack of phylogenetic understandings for genus Leporinus, its taxonomical arrangements in subgroups is based on color pattern as proposed by Britski and Garavello (1978) and successively utilized by Garavello (1979), Britski and Garavello (1980) and Garavello and Britski (1988). According to this proposition, the color pattern of Leporinus unitaeniatus and Leporinus geminis are very

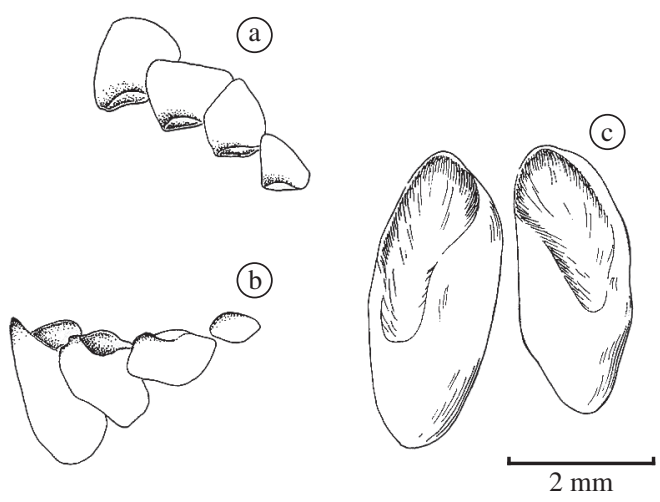

Figure 4. Lateral view of premaxillary a) and dentary teeth b) and teeth crow c) of L. geminis (after Santos and Jégu, 1989). similar to that of Leporinus melanopleura Günther and Leporinus taeniatus Lütken from the Rio São Francisco and northeastern rivers of Brazil respectively. Also Leporinus vanzoi Britski and Garavello from Rio Tapajós have similar color pattern.

On the other hand, the species included by Britski and Garavello (1980) in their "striatus group" might be similar to the species herein described because they are characterized by one or two longitudinal stripes running along dorsal flanks and lateral line. In fact among the species similar to Leporinus striatus Kner, only five species have just one longitudinal stripe along middle flank and 12 to 14 short dorsal transversal dark bars on dorsum: Leporinus melanopleura Günther, 1864, L. taeniatus Lütken, 1874, L. amblyrhynchus Garavello and Britski, 1987, L. taeniofasciatus Britski, 1997 and L. vanzoi Britski and Garavello, 2006. Those species despite having the color pattern very similar to the new species herein described are distinguished from them by having the longitudinal dark brown stripe continued from the opercular region to the caudal peduncle. The new species are distinguished from $L$. melanopleura mainly by dental formula $4 / 4$ (versus $3 / 4$ ), by the number of scales on transverse line: $6 / 5$ (versus $5 / 5$ in L. melanopleura); moreover the longitudinal stripe in the lateral line is faded on the anterior region of the trunk in L. melanopleura. The new species are distinguished from L. taeniatus by the dental formula: $4 / 4$ teeth (versus $3 / 4$ ), by the number of transverse line scales series: $6 / 5$ (versus $4 / 4$ or $4 / 3$ ) and by the longitudinal dark brown stripe along lateral line that is continuous and running in zigzag from the opercular region to caudal peduncle in L. taeniatus. They moreover differ from L. amblyrhynchus, a species from the Upper Paraná River system that has: inferior mouth in the adult (inferior margin of the superior lip horizontally aligned with the inferior region of orbit); $3 / 3$ teeth; 37 to 40 perforated scales in the lateral line; $4 / 4$ scales in the transverse series and 12 circumpeduncular scales. It differs also from L. taeniofasciatus, a species from the Araguaia-Tocantins river system that has 4/4 teeth; 3738 scales in the lateral line and 4.5 to $5 / 4$ to 4.5 scales in the transversal line, and from $L$. vanzoi a species from Rio Tapajós that has 36 to 39 scales in the lateral line.

Morphometric characters of the new species and L. taeniatus, the species that seems to be the most similar to them, was compared through free size canonical variate analysis (Bookstein et al., 1985) and the result may be seen in Table 2 and Figure 5. This analysis between samples of L. taeniatus Lutken, L. unitaeniatus n. sp. and L. geminis n. sp., showed the different morphometric pattern between these species; the first canonical variate explained $97.4 \%$ of the variation between the combined samples, while the second canonical variate explained $86.8 \%$ of the variation, giving strong indication for morphometric synthesis that is contained in the comparison of the canonical variates I and II. According to Table 2 and Figure 5, the values of morphometric characters: caudal peduncle depth $(-0.898313)$; trunk 
Table 2. Size free canonical variate analysis of Leporinus geminis n. sp. $(\mathrm{n}=12)$; Leporinus unitaeniatus $\mathrm{n}$. $\mathrm{sp}$. $(\mathrm{n}=13)$ and Leporinus taeniatus Lütken $(\mathrm{n}=5)$. Variable loadings for canonical axis I and II.

\begin{tabular}{lrr}
\hline \multicolumn{1}{c}{ Variable } & \multicolumn{1}{c}{ CAN I } & \multicolumn{1}{c}{ CAN II } \\
\hline Percent variance & 95.701200 & 0.022060 \\
Standard length & 0.831312 & 0.218856 \\
Head length & -0.108485 & -0.208783 \\
Trunk length & 0.860965 & 0.255553 \\
Body depth & -0.153950 & 0.798283 \\
Predorsal distance & 0.668001 & 0.278833 \\
Snout length & -0.026415 & -0.268718 \\
Interorbital distance & -0.537031 & -0.033028 \\
Orbital Diameter & 0.006259 & 0.945302 \\
Caudal peduncle depth & -0.898313 & 0.166887 \\
\hline
\end{tabular}

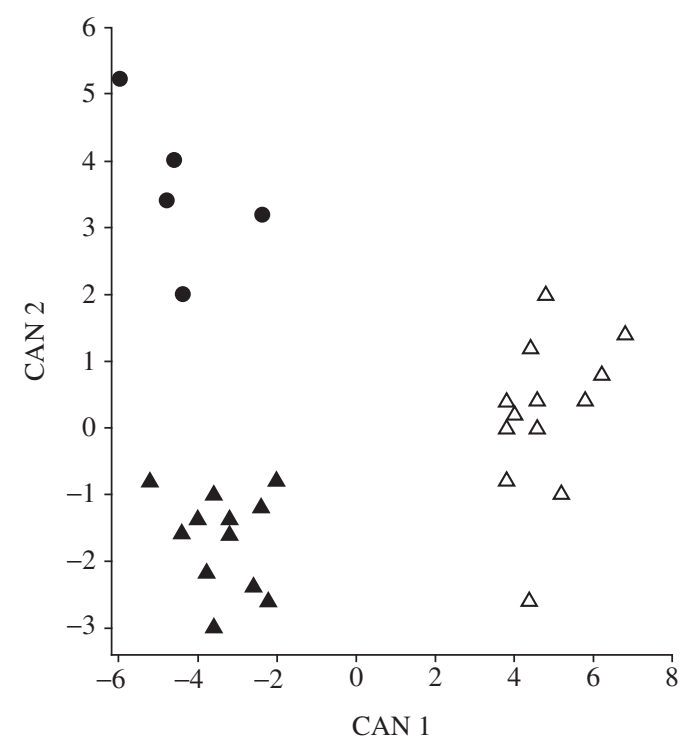

$\Delta$ L. geminis $\quad \Delta$ L. unitaeniatus $\bullet$ L. taeniatus

Figure 5. Scatter plots of scores on the space of first two canonical variables, from the size-free canonical variate analysis of Leporinus geminis n. sp, L. unitaeniatus n. sp. and L. taeniatus Lütken.

length (0.860965); standard length (0.831312) and predorsal distance (0.668001) showed better discriminating populations of the new species and L. taeniatus along the canonical variate I. On the other hand, orbital diameter (0.945302), body depth (0.798283) and snout length $(-0.268718)$ were confirmed as the differential morphometric characters along the canonical variate II. So, L. unitaeniatus differs from $L$. geminis and both from $L$. taeniatus by its proportionally more elongated body and mainly by its deeper caudal peduncle; the

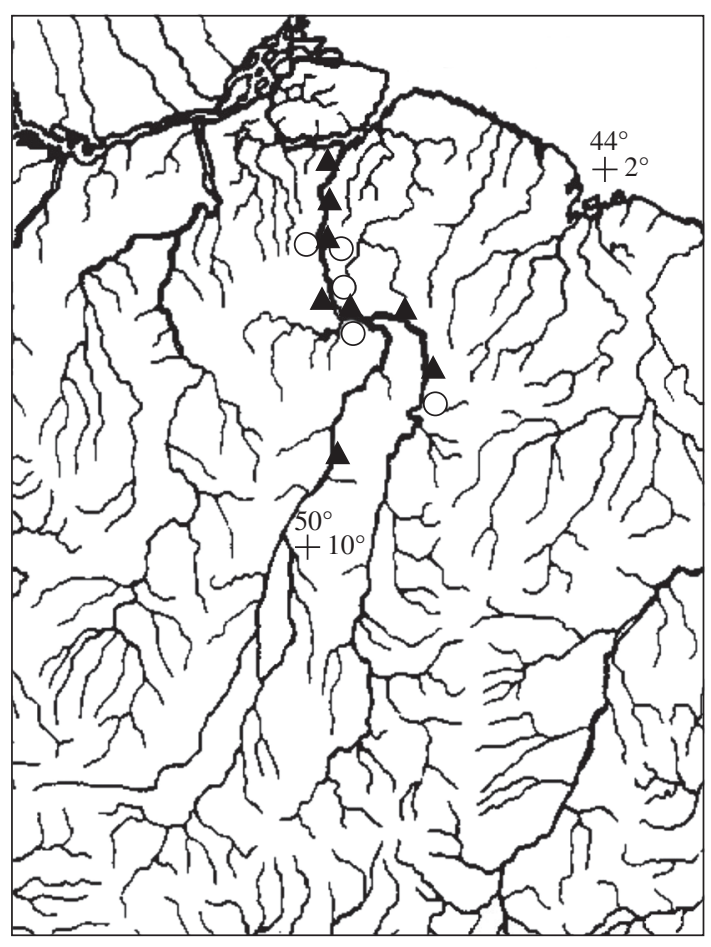

$\Delta$ Leporinus unitaeniatus $\bigcirc$ Leporinus geminis

Figure 6. Geographical distribution of Leporinus unitaeniatus n. sp. and Leporinus geminis n. sp. from the Araguaia-Tocantins system. Each symbol may represent more than one sample.

larger orbital diameter and the elongated snout; also the deeper body make $L$. geminis discriminated in relation to L. unitaeniatus and L. taeniatus.

Comparative material: Leporinus vanzoi: MZUSP 62545, 2, Rio Arinos, Ilha do Túlio, nearly $3 \mathrm{~km}$ upriver from the mouth of the Rio Tapajós, MT $\left(10^{\circ} 27^{\prime} \mathrm{S}\right.$ and $58^{\circ} 17^{\prime}$ W); 24-25 July 1997, F. R. Machado et al.; MCP 30062, 2, Rio Arinos at raft point between São José do Rio Claro and Nova Mutum, São José do Rio Claro, MT, 17 January 2002, R. E. Reis, L. R. Malabarba and E. H. Pereira; MCP 32315, 3, Rio Arinos at raft point between Nova Maringá and Tapurah, Tapurah, MT; 18 January 2002, R. E. Reis, L. R. Malabarba and E. H. Pereira.

Leporinus taeniatus: Rio São Francisco: MZUSP 14522, 2, Pedrinhas, Petrolina, C. de Souza, 20 August 1976; Minas Gerais State; MZUSP 14523, 2, Represa de Três Marias, Três Marias, H. A. Britski and I. Dias, February 1965; MZUSP 14524, 7, Três Marias, H. A . Britski and I. Dias, 14 to 18 February 1965; MZUSP 14525, 3, Represa de Três Marias, Três Marias, H. A. Britski and I. Dias, 14 to18 February 1965.

Acknowledgements - We would like to express our gratitude to Drs. Heraldo A. Britski of the MZUSP, Lucia R. Py-Daniel and Jansen Zuanon of INPA for the extensive loan period of 
specimens housed in the respective collection. My sincere thanks to Alexandre K. Oliveira of UNICEP for laboratory assistance, help with tabs, map, photos and other suggestions. Cristiano R. Moreira and Heraldo A. Britski of the MZUSP read the manuscript and made useful suggestions. Maria L. Musarra and Francisco M. S. Braga helped with the field work. We also thank the Conselho Nacional de Desenvolvimento Cientifico e Tecnológico $(\mathrm{CNPq})$ for the continuing grant to the senior author.

\section{References}

BOOKSTEIN, F., CHERNOFF, B., ELDER, R., HUMPHRIES, J., SMITH, JG. and STRAUSS, R., 1985. Morphometrics in Evolutionary Biology. Philadelphia, USA: The Academy of Natural Sciences of Philadelphia. (Special Publication 15).

BORODIN, NA., 1929. Notes on some species and subspecies of the genus Leporinus Spix. Memoirs of the Museum of Comparative Zoology, vol. 50, no. 3, p. 269-290, pls. 1-17.

BRITSKI, HA., 1997. Descrição de duas espécies novas de Leporinus dos rios Araguaia e Tocantins, e comentários sobre as demais espécies do gênero assinaladas na bacia (Ostariophysi, Characiformes, Anostomidae). Comun. Mus. Ciênc. Tecnol., PUCRS, Ser. Zool, vol. 10, p. 27-43.

BRITSKI, HA. and GARAVELLO, JC., 1978. Leporinus octofasciatus Steindachner da bacia do Paraná (Pisces, Anostomidae). São Paulo. Pap. Avls. Zool., vol. 31, no. 16, p. $237-250$.

-, 1980. Sobre uma nova espécie de Leporinus da bacia amazônica (Pisces, Anostomidae) com considerações sobre $L$. striatus Kner, 1859 e espécies afins. São Paulo. Pap. Avls. Dep. Zool. vol. 33, no. 15, p. 253-262.

-, 2005. Uma nova espécie de Leporinus Agassiz, 1829, da bacia Amazônica (Ostariophysi: Characiformes: Anostomidae).
Comum. Mus. Ciênc. Tecnol., PUCRS, Ser. Zool. vol. 18, no. 2, p. $75-83$.

CASTELNAU, F., 1855. Animaux nouveaux ou rares recueillis pendant l'expedition dans les parties centrales de l'Amerique $d u$ Sud etc. II. Poisson. Paris.

GARAVELLO, JC., 1979. (unpublished). Revisão taxonômica do gênero Leporinus Spix, 1829 (Ostariophysi, Anostomidae). São Paulo: Instituto de Biociências da USP. 451 p. [Tese de doutorado].

-, 1989. Leporinus microphthalmus n. sp. da bacia do Rio Paranaíba, Alto Paraná (Pisces, Anostomidae). Rev. Bras. Biol. = Braz. J. Biol., vol. 49, no. 2, p. 497-501.

GARAVELLO, JC., and BRITSKI, HA., 1988. Leporinus macrocephalus sp. n. da bacia do rio Paraguai (Ostariophysi, Anostomidae). São Paulo. Naturalia, vol. 13, p. 67-74.

-, 2003. Family Anostomidae, p. 71-84. In REIS, RE., KULLANDER, SO. and FERRARIS Jr., CJ. (Eds.). Check List of the Freshwater Fishes of South and Central America. Porto Alegre: Edipucrs.

GÉRY, J., 1960. Contributions a l'étude des poissons Characoïdes (7). Validité de Leporinus despaxi Puyo et du sousgenre Hypomasticus Borodin. Bull. Mus. Nat. Hist. Nat. Ser. 2, vol. 32 , no. 3, p. 222-229.

JOHANNES, T., 1999. Vorstellung der Revision der Gattung Leporinus und die Lösung eines Artproblems mit Hilfe dieser Arbeit. BSWW Report, vol. 11, no. 3, p. 14-25.

SANTOS, GM., JÉGU, M. and LIMA, AC., 1996. Novas ocorrências de Leporinus pachycheilus Britski, 1976 e descrição de uma espécie nova do mesmo grupo na Amazônia Brasileira (Osteichthyes, Anostomidae). Acta Amazônica, vol. 26, no. 4, p. 265-280.

VALENCIENNES, A., 1850. In CUVIER, G. and VALENCIENNES, A. Historie Naturelle des Poissons. Tome Sixième. v. 22: i-xx + 1 p. +1-532 + 1-91, Pls. 634-650. Paris et Strasbourg. 